\title{
Vaikuttajat haastoivat aikansa naiskuvan
}

Riitta Mäkinen \& Marja Engman (2014) (toim.). Naisten aika. Valkoinen varis ja muita oppineita naisia. Gaudeamus. 334 s. ISBN: 978-952-495-372-6

VAASALAISEN LAAMANNIN TYTÄr Rosina Heikel (1842-1929) oli Suomen ainoa naislääkäri lähes kahden vuosikymmenen ajan. Päätös kouluttautua lääkäriksi oli mitä radikaalein, vaikka veljien esimerk- ki oli ratkaiseva. Opintiellä oli kuitenkin monta estettä, ennen kuin vuoden 1871 keisarillisella määräyksellä lääketieteen yliopistolliset opinnot avattiin vakavan kutsumuksen omaaville naisille.
Heikel oli yksi niistä lasikattojen puhkojista, joista kertoo tietokirjailija, VTL Riitta Mäkisen ja FT Marja Engmanin teos Naisten aika, Valkoinen varis ja muita oppineita naisia. Valkoisella variksella viitataan räväk- 
kään poikatyttöön, punatukkaiseen Tekla Hultiniin (1864-1943), aktiiviaikansa kenties merkittävimpään vaikuttajanaiseen, äänioikeustaistelijaan ja nuorsuomalaiseen kansanedustajaan.

Viidentoista uranuurtajanaisen esittelyssä kriteerinä on oppineisuus ja koulutus, olkoonkin, että toisen keskeisen voimahahmon, Aleksandra Gripenbergin (1857-1913), ainoaksi muodolliseksi koulutukseksi jäi Helsingissä käyty rippikoulu.

Teoksen toimittajat määrittävät "naisten ajaksi" vuosikymmenet 1900-luvun taitteen molemmin puolin. Tuolloin naiset nousivat toimimaan aktiivisesti oikeuksiensa ja Suomen itsenäistymisen puolesta. Opintielle raivautumista edesauttoi useimmilla nuorilla naisilla keskivertoa vakaampi yhteiskunnallinen tausta. Mutta esipuheessa todetaan yläluokan tyttärille olleen varallisuudestaan huolimatta vaikeampaa päästä kouluun ja yliopistoon kuin porvaristyttöjen, sillä nouseva keskiluokka oli yläluokkaa aktiivisempaa ja ennakkoluulottomampaa.

\section{NAISKUVAN UUDISTAJAT}

Teoksen esittelemät kolme ensimmäistä naista olivat vallinneen naiskuvan räjäyttäjiä. Kemisti Lydia Sesemann (1845-1925) oli ensimmäinen tohtoriksi väitellyt suomalaisnainen. Viipurilaisen tukkukauppiaan tytär teki sen Zürichissä, jossa yliopisto oli avautunut myös naisille. Aleksanterin yliopiston tiedustellessa mahdollisuutta samaan Pietarista vastattiin, että jokaisen anomus harkittaisiin erikseen. Vaikka Lydia oli ensimmäinen luonnontieteistä väitellyt nainen Euroopassa, tiedemaailma unohti hänet täysin ja hänen eli elämänsä Münchenissä ja Lausannessa koulutustaan hyödyntämättä.

Ohdakkeinen oli myös Rosina Heikelin koulutus, ei vain sukupuolen tähden, vaan myös siksi, että häneltä puuttui ylioppilastutkinto eikä hänestä tullut lääketieteen lisensiaattia, vaikka hän vuonna 1878 suoritti kaikki siihen vaadittavat tentit. Pitkästä praktiikkaurastaan huolimatta hän ei ollut laillistettu lääkäri eikä häntä valittu virkoihin. Naisena hän myös jäi keskinäisen kollegiaalisen kokemustenvaihdon ja neuvojen kysymisverkostojen ulkopuolelle.

Heikel vaikutti näkyvästi ruotsinkielisen lehdistön kautta ajaen vaarallisien tartuntatautien kuten kupan viranomaisvalvonnan ulottamista prostituoitujen lisäksi myös miehiin sekä arvostellen sukupuolisesti epätasa-arvoista Lääkintähallituksen asetusta vuosisadan vaihteessa. Heikel teki elämäntyönsä Vaasassa pitäen vastaanottoa keskiluokan naisille ja poliklinikkaa työväenluokan naisille.

Ahvenanmaalaista, köyhistä oloista ponnistanutta Emma Irene Åströmiä (1847-1934) tekijät kutsuvat legendaksi jo eläissään. Åström oli ensimmäinen Suomessa valmistunut maisteri. Loistokkaassa promootiossa juhlijoihin lukeutui itse Sakari Topelius. Åströmin tausta ja elämänvaiheet antavat aineksia legendalle ja sitä käytti hyväkseen vuonna 1885 ruotsalainen feministi ja kulttuurivaikuttaja Ellen
Key, joka kirjoitti Emma Åströmin elämäntarinan. Teoksen mukaan Keyn kertomus toistui sen jälkeen kyseenalaistamatta myöhemmissä Åström-elämänkerroissa.

Kotiopetuksen varassa varttunutta saaristotyttöä Emma Åströmiä ajoi sammumaton tiedonnälkä, joka kohdistui ennen kaikkea latinan kieleen. Rippikoulusta tuli Emman käännekohta: pastori tajusi tytön erityispiirteet ja hänen painostuksestaan isä Åström hyväksyi tytön pyrkimisen Jyväskylässä perustettuun opettajaseminaariin. Ruotsinkielinen ummikko matkusti manner-Suomeen suomenkieliseen kouluun hankkimaan itselleen ammatin ja pääsi seminaarin johtajan Uno Cygnaeuksen suojelukseen.

"Oppiminen oli helppoa. Koko nelivuotisen seminaarin ajan Emma Irene oli paras oppilas ja valmistui opettajaksi kesäkuussa 1869 loistavin arvosanoin kurssinsa priimuksena", hehkutti Key. Cygnaeus toivoi suojattinsa menevän oitis opettajaksi, joista oli huutava puute. Mutta uppiniskainen tyttö halusi yliopistoon. Ylioppilastutkinto oli tuolloin yliopiston sisäänpääsykoe. "Jo pelkkä ajatus, että nainen suorittaisi ylioppilastutkinnon ja harkitsi yliopisto-opintoja, oli liki vallankumouksellinen”, Emma Åströmistä artikkelin kirjoittanut Mervi Kaarninen toteaa Naisten ajassa.

Emma piti päänsä. Hänen opiskeluaan leimasi asketismi: lukemista yöaikaan, aamiaiseksi ja illalliseksi pala leipää ja päälle vettä. Mutta maisteriksi valmistuttuaan hän täytti Uno Cygnaeuksen odotukset. Hänet valittiin Tammisaaren seminaarin lehtorin virkaan ja tätä 
tehtävää hän hoiti 26 vuoden ajan. Emma Irenen tiedonnälkää kuvataan pakkomielteiseksi: "Hänen elämänsä tapahtuu historiattomassa tilassa... Hän ei koe katovuosia, ei 1800-luvun muutoksia, ei suurlakkoa, eduskuntauudistusta, itsenäistymistä tai sisällissotaa."

\section{YHTEISKUNNALLISEN}

\section{TILAN RAIVAAJAT}

Entä muut Naisten ajan oppineet naiset? Yksitoista kiehtovaa elämäntarinaa. Ruustinna Nora Pöyhönen (1849-1938) tajusi, että valistus leviää käytäntöön naisten kautta. Hän perusti Haapavedelle Pohjois-Pohjanmaalle kasvitarhaja keittokoulun ja toimi elinikäisesti sen johtajaopettajana kouluttaen suuren määrän maaseudun vähävaraisia naisia määrätietoisin ottein. Hän kokeili monipuolisesti uusien hyötykasvien viljelyä ja kehitti tuttuja lajeja.

Karolina Eskelin (1867-1936) oli ensimmäinen Suomessa väitellyt nainen. Hän on jäänyt historiaan lisäksi Kirurgisen sairaalan perustajana. Hänen lähtökohtansa olivat kehnot. Juopon isän kuoltua yksinhuoltajaäiti luisui köyhyyteen ja tyttö elätti itsensä 13-vuotiaasta. Muiden rahoittama koulunkäynti ja opintojen tenttiminen poikakoulun kautta vaati suunnatonta urheutta ja luottamusta. Ylioppilastutkinnon suorittamiseen hän tarvitsi keisarillisen luvan. Lääkäriksi valmistuttuaan Eskelin toimi kirurgina, mutta koska keskeisimmät lääkärinvirat oli suljettu naisilta, ratkaisuksi tuli perustaa praktiikalle oma sairaala.
Karolina Eskelin oli ensimmäisiä autoilevia naisia Suomessa. Harrastus oli rakas, ja hän kuului Suomen Automobiilikerhon perustajajäseniin.

Emansipoitunut naisasianainen, aristokraattitaustainen Adelaide Ehrnrooth (1826-1905) toimi kirjailijana ja toimittajana ja polemisoi voimakkaasti naisen oikeuden puolesta omiin työtuloihinsa. Vastassa hänellä oli valtiopäivämies Agothon Meurman, jonka mielestä naisten rahankäyttö horjuttaisi avioliittoja. Kun yksikamarinen eduskunta vuonna 1906 kokoontui, naisten ensimmäinen aloite koski juuri naisten oikeutta tuloihinsa. Aloitteen laiksi teki nuorsuomalainen Lucina Hagman (1853-1946). Ruotsin mallin mukainen uusi avioliittolaki meni läpi kuitenkin vasta vuonna 1929 astuen voimaan seuraavana vuonna.

\section{NAISLIIKKEEN AKTIIVIT}

Naiset järjestäytyivät vuonna 1884 perustamalla Suomen Naisyhdistyksen. Sen näkyvimpiä hahmoja oli Aleksandra Gripenberg, josta kasvoi arvovaltainen ja itsevaltainen johtaja. Asemaa tukivat kansainvälinen naisasiakokemus sekä aatelistausta. Naisliike repeytyi vuonna 1892, kun osa näkyvistä naisista irrottautui ja perusti Naisliitto Unionin. Unioniin lähtivät Naisten ajan valikosta kirjailija ja kouluttautunut taiteilija Helena Westermarck (18571938), sokeiden kirjaston perustanut vapaamielinen Cely Mechelin (1866-1950), teoksen "valkoinen varis miesten maailmassa" Tek- la Hultin, osuustoimintaliikkeen voimahahmon Hannes Gebhardin puoliso Hedvig (1867-1961) sekä Annie Furuhjelm (18591937). Monista heistä tuli näkyviä äänioikeustaistelussa.

1900-luvun alussa siis yleinen politiikka ja syntynyt puoluelaitos naisjärjestöineen imaisivat myös emansipoituneet naiset. Vaalien tulos oli pettymys kaikkien puolueiden naisille: ensimmäiseen eduskuntaan pääsi vain 19 naista. Lucina Hagmanin lisäksi yksi heistä oli Aleksandra Gripenberg, joka Suomen kansallisbiografian mukaan on kuvaillut mielipahaansa näin:

"Suomenkieliset laskivat ruotsinkielisten suomen kielen taidosta leikkiä, sosialistit saattoivat olla 'sanoin kuvaamattomia', miehet vähättelivät naisia, pilapiirtäjät pilkkasivat henkilökohtaisuuksiin mennen ja toimintakulttuuri oli kovin patriarkaalinen. Kaiken summana tunsi olevansa 'niin kuin yksi pelikaani erämaassa'."

Gripenberg jätti eduskunnan yhteen kauteen terveydellisistä syistä. Myöhemmin sinne nousivat ruotsalaisen kansanpuolueen Annie Furuhjelm, joka nosti aktiivisesti esiin kysymyksiä, kuten kansakoululasten ravitsemuksen, kätilöiden palkkauksen, kieltolain, sairausvakuutuksen, painovapauden, Ahvenanmaan kysymyksen, siveellisyyden ja hallitusmuodon. Furuhjelm oli monarkisti.

Kiinnostava naistuttavuus Naisten ajassa on Suomen ensimmäinen naisprofessori, Åbo Akademissa tutkijanuransa tehnyt historioitsija Alma Söderhjelm 
(1870-1949). Hän omisti elämänsä ennen muuta Ranskan vallankumouksen tutkimiseen ja Marja Engmanin mukaan hänen tutkimustuloksensa ovat saaneet arvostusta niin Ranskassa kuin muualla Länsi-Euroopassa. Engman nostaa Suomen sisällissotaan liittyen Söderhjelmistä paradoksin: Vallankumouksen tutkija ei ymmärtänyt vallankumousta, kun se tuli liki, vaan vaati sodan hävinneille kostoa lehtikirjoituksissaan.

Historioitsija oli myös Kiteen kappalaisen tytär, tohtori Liisa Karttunen (1880-1957), jonka tutkimusaiheina olivat katolisen kirkon vastavallankumoustoimet Ruotsissa uudella ajalla. Roomaan jäänyt ja unohtunut Karttunen on teoksen mukaan yksi selkeimmin väärin kohdeltu ja ymmärretty naisten ajan oppinut nainen. Lu- kijan otteeseensa kietaiseva teos sivuaa lyhyesti myös elämänsä Palestiinan ja muslimielämän tutkimukselle omistanutta Hilma Granqvistia (1890-1972).

\section{URANUURTAJAT PÄÄOSASSA}

Työläis- tai talonpoikaistaustaisia naisia Naisten ajasta on turha etsiä. Valitut naiset edustavat oppineisuutta ja uranuurtajuutta. Poliittinen vaikuttaminen imaisi monet kirjan naisista Suomen valtiollisen kehityksen vedossa. Kokoomukseen siirtyivät ainakin Tekla Hultin, Hedvig Gebhard sekä kirjassa viimeisenä esitelty kulttuuripersoona Tyyni Tuulio (1892-1991).

Suoraan poliittisen vaikuttamisen valinneista naisten ajan naisista Miina Sillanpää (1866-1952) on juuri saanut oman teoksen, kun hänen syntymästään tuli kuluneeksi 150 vuotta. Teoksen Miina Sillanpää, Edelläkävijä on kirjoittanut professori Aura-Korppi Tommola. Kirjan on kustantanut Suomalaisen Kirjallisuuden Seura.

Keitä oppineita naisia Naisten aika jättää esittelemättä? Sitä lukija ei pääse tietämään, mutta ainakin koulukasvatuksen kehittämiseksi pioneerityönsä tehnyt naisasianainen ja Martta-järjestön perustaja Lucina Hagman kuuluu heihin. Varmaan moni ansioitunut ja rohkea talonpoikais-, työläis- ja nuorisoseurataustainen nainen ansaitsee kertojan elämäntyölleen, mutta yhtä lukijaa lumoavaa valikoimaa näin tuskin syntyisi. Tunnettavuudella on etunsa.

Anneli Kajanto 